9. Франко, І. Зібр. творів : у 50-ти т. / І. Франко. - К. : Наук. думка, 1976-1986. T. 30. - C. 344-538; T. 33. - C. 174; T. 34. - C. 363; T. 35. - C. 108, 230, 91-112; T. 41. - C. 47-152.

Стаття надійшла 31.03.2016 року

УДК 398(477)

Наталія Сивачук

(Умань, Україна)

\title{
ОБРАЗ РУСАЛКИ В КОНТЕКСТІ ФОЛЬКЛОРНОЇ СЕМІОСФЕРИ УКРАЇНЦІВ
}

У статті розглядається образ русалки в українському календарно-обрядовому фольклорі. Порушуються питання ритуально-міфологічної основи свята русалій, генези образу русалки, його полісемантичності $i$ поліфункціональності. Автор звертає увагу на світоглядно-духовну та художньо-семантичну його суть. Образ русалки розглядається у зв'язку з системою магічно-релігійних заборон на певні дії, з порушення яких на людину чатує страшна кара. В основі иьього образу лежить феномен табу, щзо спонукало людину вгамовувати свої інстинкти, поставити між собою і своїми природними потягами систему моральних норм.

Ключові слова: русалка, календарно-обрядовий фольклор, поліморфізм, амбівалентність, полісемантичність, табу, архетип, сакральні ключі, світоглядні уявлення, лімінальний знак, русальний тиждень.

Сивачук Н. Образ русалки в контексте фольклорной семиотики украинцев.

В статье рассматривается образ русалки в украинском календарно-обрядовом фольклоре. Анализируются вопросы ритуально-мифологической основы праздника русалий, генезис образа русалки, его полисемантичности и полифункциональности. Автор обращуает внимание на его мировоззренчески-духовную и художественносемантическую суть. Образ русалки рассматривается в связи с системой магикорелигиозных запретов на определенные действия, за нарушение которых человека ожидает страшная кара. В основе этого образа лежит феномен табу, что требовало от человека сдерживать свои инстинкты, ставить между собой $и$ своими природныли склонностями систему моральных норм.

Ключевые слова: русалка, календарно-обрядовый фольклор, полиморфизм, амбивалентность, полисемантичность, табу, архетип, сакральньее ключи, мировоззренческие представления, лиминальный знак, русальная неделя.

Syvachuk $N$. The image of mermaid in the context of Ukrainian folk semiotics.

The image of a mermaid in Ukrainian calendar-ceremonial folklore was lighted up in the article. The ritual and mythological foundations of the holiday Rusalii were discussed, as well as Ukrainian ideas about mermaid, the image of mermaid and its genesis, its polysemantic and multifunctional. The author draws the attention to the ideological, spiritual, artistic and semantic core of the image of a mermaid. The image of a mermaid was considered in the connection with the system of magic-religious prohibitions on certain acts and there violation was coming with terrible punishment. The source of the mermaid 
image was set with taboo and all that prompted man to satisfy instincts, put between him and his desires the system of moral norms.

Keywords: mermaid, calendar-ceremonial folklore, ambivalence, polysemantic, taboo, archetype, ideological ideas, transitive sign, mermaid week.

Постановка проблеми. Щоб бути повноцінними в полі цивілізованих націй, нам, українцям, треба глибоко пізнати самих себе, своє минуле, через оцінку якого осмислити, окреслити рівний шлях у майбутнє.

Серед основних завдань побудови незалежної держави постає проблема виховання національно свідомих громадян особистісного типу, патріотів, які добре знаються на рідній історії, фольклорі, міфології. Саме національна міфологія переповнена ідеями утвердження прагнення до волі, добра, краси, захисту всього живого на землі.

Саме в міфологічній свідомості витоки нашого характеру, способу мислення, світогляду, тут втілені згустки народної мудрості, моделі поведінки, моральні норми. Осмислення міфології стимулює розвиток сучасної думки, надає снаги розвивати і зміцнювати національно ідеї самобутності.

Серед нижчих міфологічних персонажів східнослов'янського пантеону чільне місце посідає образ русалки, вона ж є характерним утіленням у давньоукраїнській міфології архетипу Аніми, продуктом процесу психологічної сублімації у психічному житті наших пращурів.

Образ русалки досліджували Є. Анічков, В. Гнатюк, В. Давидюк, Д. Зеленін, О. Кісь, М. Маєрчик, А. Онищук, В. Петров, Е. Померанцева, Б. Рибаков В. Ятченко та ін.

Мета статті - розкрити образ русалки в українському фольклорі у контексті української культурної семіосфери, довести її характерні ознаки - полісемантичність, поліфункціональність.

Русалки - найцікавіший та найзагадковіший образ української нижчої міфології, якому притаманні поліморфізм i полісемантичність. В українському фольклорі маємо справу з водяними русалками, лісовими мавками, польовими нявками та берегинями. Учені прийшли до висновку, що генеза образу русалки визначається, по-перше, ї зв'язком із покійниками, по-друге, їх зв' язком із природнім середовищем [5].

У світоглядних уявленнях українців русалки - це душі дівчатутоплениць, що живуть у воді, лісі чи полі. Вони вродливі, дуже бліді, 3 довгим волоссям, оголеними тілами, люблять бавитися у воді, блукати лісами. Їх ставлення до людей завжди вороже: той, хто трапиться їм на шляху, приречений. Русалки мають позитивний вплив на родючість полів, добрий врожай злакових.

Упродовж віків сформувалася система обрядових дій, спрямованих на пошанування, задобрення русалок, які одержали назву русалій. 
Русалка живе у воді, культ якої особливо шанується українцями. У світоглядних уявленнях нашого народу склалося уявлення про воду як очисну, захисну i, в той же час, агресивну силу, яку М. Костомаров назвав «пасивною матерією жіночої сутності». У фольклорі вода персоніфікується і до неї звертаються як до живої істоти, яка навіть має ім'я Уляна.

О. Кісь визначила відмінності між проявами водної стихії на рівні повсякденних колективних уявлень українців у семантичному ряду «море - ріка - криниия -болото» [5].

Якщо море у мисленні українців постає безформною стихією, то ріка має виразні ознаки структурованості, початок і кінець (витоки, середина, гирло). Вона теж є медіатором між світами. У давнину покійників ховали на лодіях у воді. Пригадаймо звичай кидати у воду шкаралупи великодніх крашанок, щоб вони дійшли до далеких пращурів рахманів. Річка у міфологічній свідомості набуває танатологічного змісту: Стікс, Лета.

В українському фольклорі водна стихія асоціюється зі стихією людських почуттів. К. Юнг стверджував, що вода $\epsilon$ символом підсвідомого. Тому у «плані парадигматики підсвідомість повністю корелює з нижнім ярусом світобудови, тобто співвідноситься 3 темним, деструктивним, непізнавано-потойбічним, землею - водною стихією жіночим началом. Міфопоетичне ототожнення глибин власної підсвідомості людини та водної безодні знаходить свій вияв і підтвердження в аналізі різних варіантів сюжету «потоптання» у воді чи «поглинання» водою» [5, с. 109]. Вода асоціюється 3 людськими почуттями, напливом емоцій.

Регіт русалки, неадекватність поведінки є ознакою божевілля, яке на парадигматичному рівні цілком тотожні зі смертю, бо в першому випадку гине тіло, у другому - душа.

Учені вказують ще на один момент образу русалки. Це - русалка i ерос. Русалка-красуня зваблює чоловіка у воду, яка є символом почуттів. Потопати - означає занурюватися у стихію чуттєвості. У колядках та весільних піснях Дунай-море - це межа переходу від статусу дівчини до статусу одруженої жінки. Потоптання у водах означає не смерть, а тимчасове занурення в хаос задля повернення до порядку.

Русалці притаманна звабливість, гріховність, підступність. У стихії іiі почуттів прагне потонути кожен. М. Маркович писав, що «всі гарненькі малоросіянки, коли купаються, то схожі на русалок, вони ваблять голосом, не торкаючись нас, і можна із захопленням для них навіть втопитися». На цю здатність чоловіка втопитися в почуттях до жінки вказує представниця психоаналітичної школи Карен Хорні: «Чолові ніколи не втомлюється всіляко демонструвати нездоланну силу, що тягне його до жінки, i, 
одночасно страх, що через неї він може втратити себе чи навіть померти» [8, с. 102$]$.

Дослідники прийшли до висновку, що образ русалки в контексті міфопоетичної візії світу - це лімінальний знак, що стоїть на межі між космосом та хаосом, між культурою i природою, між соціальним i біологічним у самій людиниі. Розділяючи «той» $\mathrm{i}$ «ей» світи він застерігає: «Гамуйте голос вашого еросу, бо у ньому відлунює поклик танатосу!» [5, с. 110] або «Дай серцю волю - заведе у неволю».

Русалки зваблюють молодих людей фертильного віку, які ще повинні народжувати дітей, дбати про їхнє майбутнє. У світоглядних уявленнях українського народу розбещеність почуттів, гріхи батьків можуть позначитися на долі дітей і внуків. Символом спокуси стало яблуко, яке, як відомо, «від яблуньки далеко не падає».

Учені вважають, що русалкам притаманні такі характерні ознаки:

по-перше: це істота жіночого ролу (як правило, молода дівчина або жінка фертильного віку);

по-друге: вона має підкреслено еротизовану зовнішність (вона вродлива, оголена, часом із гіпертрофованими статевими ознаками);

по-третє: вона приваблює своєю поведінкою (співом, голосом, сміхом тОщо);

по-четверте: вона вороже ставиться до людей, таїть у собі приховану загрозу, вона підступна й небезпечна, будь-який контакт чи зближення 3 нею загрожує смертю;

по-П'яте: смерть від русалки має вигляд потоплення чи божевілля (блукання, залоскотування, гіпнотичний стан від співу, марення тощо);

по-шосте: вона має ознаки тонічності (риб'ячий хвіст, здатність перетворюватися на жаб, щурів, поява у нічний час) та причетності до потойбічних сил (здатність передбачати майбутнє, надавати людині надприродних властивостей.

Зелений тиждень в Україні починався 3 четверга. Як пише О. Воропай, дівчата в цей день ішли на поля, левади, ліс і там «завивали вінки на всі святки». На виготовлення вінків брали конвалії, васильки, чебрець, незабудки, полин. Готували також святковий обід, який складався з яєшні, сиру, хліба, пиріжків, солодощів. Головне дійство починалося в полудень. Подвір'я, куди сходяться дівчата, чисто виметене, посеред нього стоїть зрубана молода деревина, а під нею - горщик 3 водою. Кілька хлопчиків тримають в руках заготовлену іжу, а інші - відра 3 пивом на палицях. Одна 3 дівчат виділяється із гурту, підходить до дерева і перекидає горщик з водою. А потім бере дерево в руки і заспівує пісню ... 3 їі голосом поєднуються голоси інших. Ворота відчиняються, i весь гурт, оточивши дівчину з деревом, рухається по вулиці в напрямку до 
лісу. У лісі розстеляють обрус, ставлять іжу і питво, сідають навколо i починають святкову трапезу.

Після пиру дівчата вибирають берізку, щоб завивати на ній вінки. Вони розділяються по двоє, і кожна пара 3 гілля в’є собі один вінок, не відриваючи гілочки від дерева. Після того, як вінок готовий, кожна пара «кумається»: обмінюються крашанками через вінок і цілуються. Потім приступають до вибору старшої куми: скручують хустки, кидають їх угору. Чия хустка підлетить вище, та й буде старшою кумою.

Ой кумочки та голубочки, Ми у ліс ідем, ми кумиться йдем!

I покумимося, й поголубимося!
А на дубочку два голубочки:

Вони кумляться,

обіймаються й пригортаються.

Вінки, які дівчата завивають на березі, у контексті русалій символізують сакральні ключі. Ці гілки завиваються в гіллі живих, а не зламаних гілок. На дереві, що виросло на межі двох світів, дівчата завивають вінки-ключі, кола, через які намагаються заглянути у своє майбутнє. У світоглядних уявленнях українського народу ключі - символ долі. Загубити ключі - загубити долю. Символічним втіленням сакрального ключа у контексті русального свята є вінки, завиті на березі. Через ці віконця-вінки дівчата намагаються побачити майбутнє, «кумаються» та обмінюються жовтими крашанками. Завиваючи вінки на всі дні свят, дівчата ніби створювали магічний «тунель», через який до них могли прийти душі близьких померлих» [9, с. 198]:

Ой зав'ю вінки та на всі святки,

Ой на всі святки, на всі празники,

Бо в садочку весна розвивається,
Дочка батька дожидається: «Ой, мій батеньку, мій голубоньку Та прибудь хоч на хвилечку».

Учені (О. Веселовський, В. Давидюк, Д. Зеленін) підкреслюють, що русалії в українців в основному мали форму поминальних обрядів. Упродовж русального тижня на столі залишали хліб, масло, відро з водою і щодня вішали свіжий рушник. Залишивши двері відкритими, господарі виходили 3 хати, а деколи навіть 3 подвір'я, щоб не наполохати русалок, коли вони прийдуть обідати. Удосвіта на тичку вішали свіжу сорочку. Особливо дотримувалися цього звичаю в хатах, де впродовж року були покійники [4, с. 148].

У пісні русалка просить у жінок намітки, а в дівчат сорочки:

Сиділа русалка

На кривій березі,

Росила русалка

В жіночок наміток,

В дівочок сорочок:
Жіночки-подружки, Дайте мені намітку! Хоч вона худенька, Та аби біленька. 
В. Давидюк вважає, що уявлення про те, що русалка потребує сорочки, може бути подвійного походження. 3 одного боку воно може асоціюватися з утопленицями, які не мали на собі одягу під час купання. 3 іншого - певний стосунок до цього, причому набагато архаїчніший i вмотивований ритуально, може мати обряд «куста», який так само відбувався на русальному тижні [4, с. 148].

На «куста» вибирали найвродливішу дівчину. Дівчата збиралися в лісі, роздягали іiі повністю або залишали в самій сорочці, далі 3 ніг до голови вбирали в зелень. Відколи з русалки знімають весь одяг чи умовно лише його частину, що однаково означає відчуження від атрибутів цього світу, вона сприймається як хтонічна істота [4, с. 148].

Вчені вказують, що ритуал широко застосовує знакові властивості одягу, а його елементам відповідають певні частини тіла (капелюх голова, рукави - руки, штани/спідниця - ноги) [6, с. 27]. Тому роздягання символізує розбирання тіла на складові, деструкцію, владу хаосу. Роздягають людину тоді, кола вона переходить межу двох світів, а також під час ініціації. Русалка перейшла межу між світами, вона - представниця «того» світу, на це вказує її оголеність. Щоб у Зелені Свята стати своєю у світі живих, потрібно одягнутися, це спонукає їх просити «у жіночок намітки, а в дівочок сорочки».

Тема амбівалентності образу русалки звучить у русальній пісні «Ой біжить, біжить мала дівчина». Красуня-русалка задає дівчині сім загадок, сповнених сакрального змісту, які може розгадати лише дуже мудра людина:

А щуо грає - голос має?

А щзо плаче - сліз не має?

А щөо біжить без пригону?

А що світить в ясну пору?
А щео в'ється круг деревия?

А що горить без полум'я?

А щчо росте без кореня?

Коли той, кого питають, дає відповідь на запитання, в цей момент між ним і тим, хто питає, починається діалог, у процесі якого його учасники на мовному рівні відтворює процес народження світу. Подібний ланцюг загадок ніби проживає весь світ від початку часів до сьогодення, акцентує тим самим вертикальну вісь. Відповіді на загадку становлять алфавіт світобудови в рамках цієї міфопоетичної традиції. А. Байбурін відзначає, що мета i смисл ритуалів розгадування в тому, щоб перевірити збереженість «словника» картини світу колективу через певний проміжок часу [1, с. 133].

Учені висловлюють гіпотезу, що процедура загадування-відгадування відбувалася не в будь-який часовий момент, а прив'язувалась до певного ритуалу. По-перше, вони були приурочені до Нового року, коли світ 
розпадається на Хаос і треба через відтворення ситуації першотворення знову перетворити його в Космос. По-друге, вони були засобом ініціації жерців, коли перед жертвоприношенням влаштовувалися їх словесні змагання, у процесі якого вони повинні продемонструвати знання сокровенного змісту. Загадка передбачає не послідовний перебір усіх можливих варіантів, а знання єдино правильної відповіді. Ця вимога пояснюється власне призначенням ритуалу загадування, мета якого перевірити на здатність та уміння логічно мислити, а знання алфавіту світобудови [7, с. 46].

В українському фольклорі чітко простежується мотив смерті того, хто розгадав загадки царівни. Смерть чекає на дівчину-семилітку, яка не розгадає русалчиних загадок. Русалка живе у водній глибині, а з водними глибинами у наших пращурів було пов'язано розуміння безмежної, глибинної мудрості. Русалка пізнала ці глибини мудрості, таємницю буття, тому своєю згадкою намагається перевірити знання людьми азбуки світобудови. «Здатність знати про все на світі - характерна ознака представників «того світу», мабуть, пояснюється уявленнями про піклування духів предків про добробут своїх родичів, уміння володіти природними стихіями. Можна припускати, що саме 3 віщуванням, як пізнанням усіх секретів природи, пов'язані мотиви загадування русалками загадок, відомих русальних пісень» [4, с. 148].

У своєму звичайному, земному і профанованому світі людина ніяк не могла не дізнатися про походження Всесвіту і про вищі цінності буття. Ці унікальні знання можна почерпнути тільки зовні, з глибин світових вод, які таємним чином одночасно виявились i океанським безмежжям, $\mathrm{i}$ небесною висотою, і глибинами несвідомого людини. Божество, що панує у морському безмежжі, могло поділитися мудрістю з тими, хто іiі прагне, дати побачити приховану від простих смертних картину істинного космічного буття, дарувати прозріння та багатство духу. За легендою такі знання містила міфічна «Голубина книга». Таке бачення мудрості висловив I. Франко:

Книги - морська глибина, Хто в них пірне аж до дна,
Той, хоч і труду мав досить, Дивнії перла виносить.

Дослідники вважають, що не варто недооцінювати значення простих, на перший погляд, русалчиних запитань. Людина звернула свій допитливий розум до довкілля і стала дошукувати сокровенні таємниці його будови. Скоро просте спостереження над білим світом перестало цікавити людину i вона задумувалася над таємницею буття. Видимий космос став загадкою для людини - як стосовно питання, поставленого перед нею самою, так і стосовно таїни буття. По суті, ця ж методологія 
лежить в основі сучасної науки, коли вчений зустрічається з незрозумілим явищем природи, дослідник формулює для себе питання і сам же шукає відповідь на нього, намагається розгадати ту чи іншу таємницю буття. Такі міркування привели фольклористів до думки, що загадки є справді «переднаукою», оскільки вперше учать людину класифікувати i упорядковувати світ, тим самим робити його доступним до наступного вивчення [7, с. 52].

У дохристиянські часи анімістичний світогляд наших пращурів дозволяв дивитися на світ як на суцільне буяння життя, а природа сприймалася одухотворено. Люди відчували, що простір довкола переповнений духами, які не викликали у людей страху, оскільки вони мали високу культуру єднання 3 природою. Сучасною мовою ідею духів можна передати терміном «енергетичне поле», «психічна енергія».

«Віщим в усіх легендах виступає упир. Часом віщунство є причиною його непогамованості після смерті. Воно притаманне й потерчатам», пише В. Давидюк у праці «Українська міфологічна легенда» [4].

Русалки-потопельниці, на думку М. Чумарної, діти-семиліточки, які володіли великими знаннями, тому й від живих вимагали мудрості.

Проводи русалок відбувалися на перший день Петрівки або на Вознесіння. Дівчата готують тризну в полі на честь русалок, після якої ходять по полях $з$ розплетеними косами і вінками на голові [2, с. 349]. Святкування Русалій, як поклоніння богині води Дані, «матері русалок», завершувалося поводами русалок. Ця тема знайшла своє відображення в русальних піснях:

Проводили, русалочок, проводили, Щоб вони до нас не ходили, Та нашого житечка не ломили, Та наших дівочок не водили.

Проведу я русалоньку до бору. А сама піду додому. Ми свою русалоньку проводили, Гіркою осикою заломили.

Згідно з етнографічними записами, проводи русалок відбувалися на полях [2, с. 350] у «десятий понеділок», перший день Петрівки [2, с. 349] i мали оказіонально-утилітарний зміст - накликати багатий урожай збіжжя на полях. Згодом це дійство набуло розважального змісту. Дівчата готували спільний обід в полі, тризну, після якої співали пісень.

Професор В. Давидюк вважає, що дівчата проводили русалок «до бору», в жито, за село, на могилки, на міст, до води, тобто, за міфологічними уявленнями, - на порубіжжя, у так звані «зони смерті» [4, с. 160]. Учений висловлює думку, що тільки після цього русалка починає поводитися як істота, пов'язана 3 тим світом i водночас як жертва, що прагне потягнути за собою когось із близьких. Він пише: «Стає абсолютно 
ясно, що обрядова «русалка» грає роль реальної жертви, для якої обиралася найкраща дівчина» [4, с. 160].

У русальних піснях відбився весь спектр світоглядних уявлень нашого народу про обрядовість, у контексті якої вони виконувалися.

Отже, осмислення образу русалки в українському календарнообрядовому фольклорі спонукало нас до висновку про те, що він:

- полісемантичний та полі функціональний;

- $\epsilon$ лімінальним знаком між космосом та хаосом, між культурою i природою, між соціальним і біологічним у самій людині;

- $є$ регулятором моральної поведінки людини;

- $\epsilon$ образом дівчини-жертви, яка проходить обряд ініціації.

\section{СПИСОК ВИКОРИСТАНОЇ ЛТЕРАТУРИ}

1. Байбурин, А. К. Загадки и ритуал / А. К. Байбурин // Этнолингвистика текста. Семиотика малых форм фольклора. - М., 1988. - С. 133-135.

2. Воропай, О. Звичаї нашого народу [Текст] : етногр. нарис / Олекса Воропай. Х. : Фоліо, 2005. - 508 с. - (Перлини української культури).

3. Гримич, М. В. Зелені свята / М. В. Гримич // Родовід. - 1993. - № 5. - С. 20-29.

4. Давидюк, В. Первісна міфологія українського фольклору / В. Ф. Давидюк. 3-тє вид., доп. й перероб. - Луцьк : Волинська обласна друкарня, 2007. - 320 с.

5. Кісь, О. Дівчина русалка: зваба безодні (імпліцитний код) / О. Кісь // Студії $з$ інтегральної культурології. 1. Танатос. - Львів, 1997. - С. 105-112.

6. Маєрчик, М. Ритуали родинного циклу крізь призму моделі переходу / Марія Маєрчик // Спец. випуск «Народознавчих зошитів». - № 2 : Студії 3 інтегральної культурології. Ритуал. - Львів, 1999. - С. 18-31.

7. Серяков, М.Л. «Голубиная книга»- священное сказание русского народа / М. Л. Серяков. - М. : Алетейа. 2001. - 664 с.

8. Хорни, К. Страх перед женщиной (сравнение специфики страха женщины и мужчины по отношению к противоположному полу) / К. Хорни // Хорни К. Женская психология. - СПб., 1993. - 224 с.

9. Чумарна, М. 3 початку світу : Україна в символах [Текст] / М. Чумарна ; передм. автора. - Вид. 2-е, доп. - Л. : Сполом, 2005. - 285 с.

Стаття надійшла 29.02.2016 року

УДК 821.161 .2

Павло Ямчук

(Умань, Україна)

\section{ФЕНОМЕН ГРИГОРІЯ КОСИНКИ В ІСТОРИКО- ЛІТЕРАТУРНОМУ КОНТЕКСТІ КІНЦЯ 1920 - ПОЧ. 1930-Х РОКІВ}

У статті вивчаються малодосліджені аспекти феномену неординарної постаті вітчизняного Розстріляного Відродження - знакового мития слова, одного з 